\title{
15 \\ Tailevu North: five years down the line
}

\section{Anare Tuitoga}

Tailevu North sprang to prominence in the 2001 election as the constituency from where the incarcerated coup leader, George Speight, was elected as an MP for the Conservative Alliance-Matanitu Vanua (CAMV). He survived only a short time as an MP, before being dismissed for missing three consecutive sittings of parliament. Yet his legacy lived on. Speight's brother became MP for Tailevu North after a by-election in 2002. In the run-up to the 2006 polls, sympathies remained strong for the imprisoned coup leader and his family. The people of the Wainibuka region, as shown in this chapter, are bati (warriors) to the powerful chiefs of Bau Island, and thus traditionally obliged to follow the Bau chiefs' backing of the more militant fringe of Fiji politics. The dissolution of the CAMV helped to draw the politics of this disadvantaged province back into the mainstream of Fiji politics, but Tailevu North remains a dissident province in Fiji's political firmament.

\section{Background}

Fiji is traditionally divided into three confederacies or matanitu: Kubuna, Burebasaga and Tovata. Kubuna is the leading matanitu and, within it, Tailevu is the principal province. The five vanua of Bau, Nakelo, Sawakasa, Verata and Wainibuka make up the province of Tailevu. The Tailevu North Constituency consists of the vanua of Sawakasa, Verata and Wainibuka. Within these three vanua are 22 tikina makawa. (Tikina is loosely translated as 'district' and was 
a colonial concept, which was introduced into the traditional Fijian structure to help ease administration by the colonial administrators. A tikina makawa is loosely translated as an old district.) Within these tikina makawa there are a total of 78 villages. Within the vanua of Sawakasa are the following tikina makawa: Dawasamu, Namena, Nailega, Namalata and Sawakasa, whilst Verata consists of Tai, Tai Vugalei, Verata and Vugalei. Naloto, Nasautoka, Nayavu and Wailevu make up the vanua of Wainibuka.

\section{Data on candidates for the Tailevu North Fiji Provincial Communal constituency}

As in 2001, 71 seats were contested in the 2006 elections. In total, there were 17 Fijian provincial constituencies. Tailevu North Fijian Provincial was contested by Laisiasa Cabenalevu of the Fiji Labour Party (FLP), Samisoni Tikoinasau of the Soqosoqo Duavata ni Lewenivanua (SDL) party, and Iliesa Duvuloco of the Nationalist Vanua Tako Lavo Party (NVTLP). ${ }^{1}$ There were 9,682 voters listed. But there were only 8,687 ballot papers counted. Of these, 923 were invalid; thus, there were only 7,764 valid ballot papers. To gain a majority the successful candidate needed to secure 3,883 votes. At the end of counting, Cabenalevu secured 312 votes ( 4.02 per cent), Tikoinasau obtained 6,281 (80.9 per cent) and Duvuloco 1,171 (15.08 per cent). Duvuloco had also contested this seat in 1999 , then gaining 1,814 votes, but losing out to Savenaca Tikoinavo, Tikoinasau's father.

In 2006, Tikoinasau was declared the elected member for the Tailevu North Fijian Provincial Communal constituency.

\section{Success of the SDL party and its candidate}

Much of Tikoinasau's success in 2006 may be attributed to the fact that he was the SDL candidate. Across the country, support for the SDL in Fijian communal constituencies was overwhelming. It secured 44.59 per cent of the national total and a total of 36 seats. The party had been founded in 2001 by the then caretaker prime minister, Laisenia Qarase, and absorbed most of the Christian Democratic Alliance and other conservative groupings. It had the informal endorsement of the Great Council of Chiefs and was seen to be a successor to the Alliance Party. The SDL has campaigned on a platform 
of economic and social advancement of the indigenous Fijians along with the development of other ethnic groups. It promoted Fijian interests and advocated that Fiji be governed by indigenous Fijians. This appealed to the indigenous voters everywhere, but especially in Tailevu North. One of the reasons why Fijians in Tailevu supported George Speight's civilian takeover in May 2000 was their wish to see the government remain in the hands of indigenous Fijian leaders. The voters of Tailevu North, we can safely say, are not ready to accept a non-Fijian as prime minister. They are not interested in a moderate manifesto, such as that of the National Alliance Party of Fiji, with its call for multiracial government. As far as these voters are concerned, people of other ethnic groups are vulagi and should not rule in their place. ${ }^{2}$ As elsewhere, voters in Tailevu were advised by the SDL to tick above-the-line, and to cast their ballot along party lines rather than for an individual. The campaign speeches that were made, advised them to place their ticks next to the symbol of the dove above the line.

Yet there were local reasons, too, that explain Tikoinasau's victory.

First, there were family ties. Tailevu North was won in 1999 by Savenaca Tokainavo, Tikoinasau's father, and in 2001 by George Speight, Tikoinasau's brother. The Speight name was well known in the Tailevu North area, and the prestige accumulated by the gaoled coup leader had some bearing on Tikoinasau's re-election - although unlike in 2002, when he was an unknown person, it was not the only factor. More important than his brother in attracting support to him was his father, Sam Speight Snr, who has served extensively in the region in his capacity as the general manager of the Rewa Dairy Company. Speight Snr was also a director of the Dritabua Dairy Farm, which is owned by the people of Naloto.

Second, Tikoinasau was the sitting member for the constituency and a minister in the Qarase government, factors which he said counted in his favour. During his four years as a sitting MP, he had been able to make a name for himself. He campaigned effectively, visiting the villages in his constituency, and using the same successful campaign team he had used in the 2002 by-election. Part of his build-up for the 2006 election included setting up a constitution office in Korovou so that he would be accessible to his voters. Korovou is the municipality of the Tailevu North constituency. 


\section{Map 15.1 The Tikina Makawa of Tailevu North Fijian Communal}

\section{TAILEVU NORTH FIJIAN COMMUNAL CONSTITUENCY}

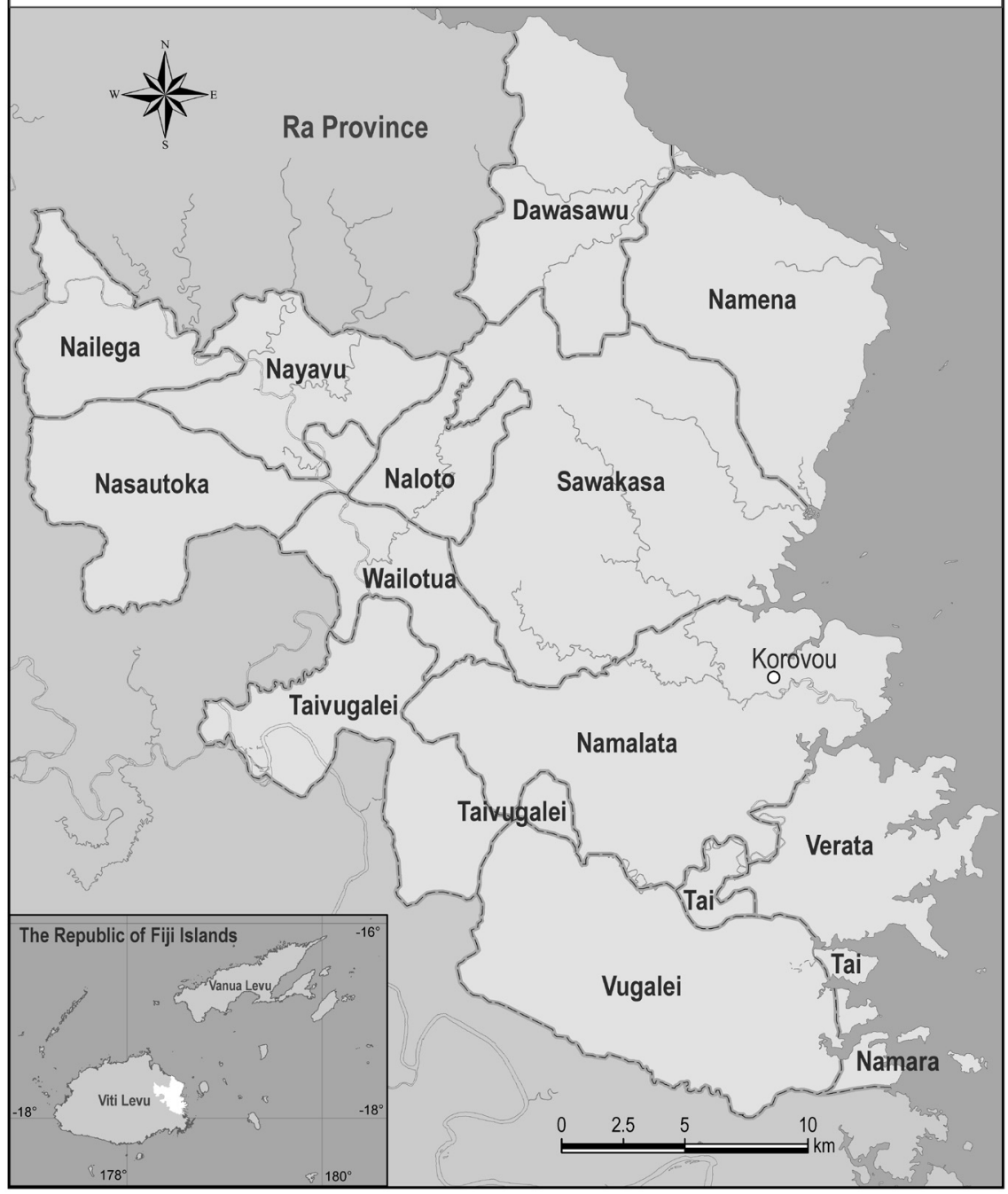

Source: Pacific Institute of Advanced Studies in Development and Governance (PIAS-DG) Mapping Database, University of the South Pacific, Suva. 
Third, there were traditional loyalties and obligations. Tikoinasau claimed that the traditional links between the tikina of Wainibuka and those of Verata and Sawakasa contributed to his victory. These tikina belong to the vanua of Waimaro. In Fijian history, before Bau became powerful in Tailevu, Verata was the dominant tikina. The people of Tailevu North are militant people. They justified their participation in the events of 2000 by stating that they are traditional bati to the Vunivalu na Tui Kaba of Bau. ${ }^{3}$ Many of the people of the tikina makawa of Namena and Dawasamu can trace their roots back to the province of Ra, the war cry of which is ' $m a^{\prime} e$ na ma'e - which loosely translates as 'they are prepared to die for what they are fighting for'. So, the people of this constituency rallied behind the SDL and Samisoni Tikoinasau, it is argued, because they believed that doing so was a fulfillment of their duty as traditional warriors fighting to retain power in the hands of indigenous Fijian leaders. While traditional loyalties clearly played their part in 2006, Tikoinasau's interpretation may need to be qualified in the light of further research, given the traditional hostility shown by Verata towards Bau, which can be traced to Verata's defeat as a great chiefdom in the 19th century, and which could still be seen in Verata's failure to support George Speight in 2000.

\section{The coalition of the CAMV and the SDL}

The coalition of the CAMV and the SDL was particularly important for Tikoinasau's electoral victory. A majority of the voters of Tailevu North had been strong supporters of the CAMV. The CAMV had been established in late 2000 and early 2001 in opposition to the direction being taken by the Soqosoqo ni Vakuvulewa ni Taukei (SVT) under the leadership of Ratu Inoke Kubuabola as the leader of the opposition in parliament. Those initially involved in establishing the CAMV included SVT MPs Ratu Naiqama Lalabalavu, Ratu Rakuita Vakalalabure and Sireli Leweniqila and, later, Senator Ratu Josefa Dimuri. Lalabalavu noted that there was a lot of disagreement amongst the SVT parliamentarians about the manner in which parliamentary leader Ratu Inoke Kubuabola was behaving. ${ }^{4}$ He was making decisions without fully consulting the other members. The SVT constitution stated that the parliamentary caucus would meet and make a decision on any issue that was to be dealt with. However, Kubuabola had gone ahead and advised Government 
House that he was available for the position of prime minister. This took place after the 1999 election.

At an emergency SVT management board meeting there was a head-on disagreement, and the group decided to form their own party to represent Vanua Levu. Lalabalavu, in his position as Tui Cakau, had visited the Tui Macuata and Tui Bua to solicit their support, and the chiefs of Vanua Levu unanimously agreed with the setting up of the CAMV and to disassociate themselves from the SVT. The result was a gradual decline in support for the SVT in Vanua Levu. At the official launch of the CAMV in June 2001, Ratu Epenisa Cakobau was appointed the president, while Ratu Naiqama Lalabalavu of Tovata and Ro Alivereti Tuisawau of Burebasaga became the two vice presidents. What this meant was that the apex of the party was represented by the leading chiefly clans of the three confederacies to which all Fijian chiefs belong. And where the chiefs went so did their subjects.

Tailevu North's inclusion in the CAMV was by default rather than by design. The leaders of the CAMV had registered the party in Labasa, the main urban centre in the north, but during one of their management meetings in Suva they received a delegation from Tailevu North requesting membership of the CAMV party. The delegation took this step because they could not form a party of their own, but, nevertheless, wanted to sever ties with the SVT. Many resented the clampdown by the military in their area that had followed the arrest of Speight and his supporters in 2000, and some still harboured rebellious sentiments. By joining the CAMV they hoped they could get George Speight set free, and revive his cause. Lalabalavu argues that the CAMV was set up primarily as a political party with its own manifesto rather than as a rebel party. ${ }^{5}$ Yet, it was widely seen as a party for the militants, and attracted followers on this basis.

When it was established, the CAMV sought to fight for the paramountcy of Fijian interests and advocated that the governing of Fiji remain in the hands of Fijians and their chiefs; in other words, that the offices of president and prime minister be reserved for indigenous Fijians. They also wanted the return and preservation of Fijian land and qoliqoli. ${ }^{6}$ This was to correct previous wrongs by way of legal processes. CAMV also sought the academic and economic development of Fijians. This appealed to the people of Tailevu North, many of whom mistakenly 
thought that by joining the CAMV their nationalistic ambitions would be fulfilled and their petition for George Speight's release would be successful.

The Cakobau family, moreover, supported the CAMV. Lalabalavu, again in his capacity of Tui Cakau, had paid a visit to the family of the Vunivalu of Bau. Lalabalavu explained that he came to the family of the Vunivalu as a vasu - a descendant of the female line. ${ }^{7}$ As is common in Fijian culture, the vasu is held with high regard and, being aware of this, the members of the Vunivalu's family joined forces with the Tui Cakau and the CAMV. As previously noted, the people of Tailevu North are bati to the Vunivalu, so wherever the Vunivalu and his family go his warriors follow, as it is their traditional responsibility to guard and protect the Vunivalu and the members of his family.

In the 2001 election, it was too late for the SDL and CAMV to coalesce, as the two parties had already been registered separately. So, it was decided that they would contest the elections separately and then form a coalition in parliament. The CAMV won six seats in 2001. The FLP tried to woo support from the CAMV in an effort to form a government after the 2001 polls, despite the party being associated with the instigators of a coup against Mahendra Chaudhry's government. Lalabalavu claims that there was an offer from the leader of the FLP to make him prime minister and Rakuita Vakalalabure the deputy prime minister. ${ }^{8}$ There was also the promise of amnesty. But the CAMV joined with the SDL instead.

In preparation for the 2006 election, at its annual general election meeting in February 2006, the party voted to dissolve itself and merge with its coalition partner, the SDL, to form the Fijian United Party. It is alleged that Ratu Tanoa Cakobau, as part of the merger, wrote a letter requesting that the six CAMV parliamentarians be endorsed unopposed as SDL candidates. But Cakobau said that certain portions of the letter were not authentic. Lalabalavu clarified that the CAMV had not set any conditions prior to the merger. ${ }^{9}$

There was some dissent surrounding the deregistration of the party. Some rebels claimed to have been railroaded into liquidating their cherished party, and that this entailed an abandonment of the ideals for which they had fought hard during 2000. Lalabalavu claimed that those within the party who opposed this decision did so because of self-interest. He had explained at the final CAMV meeting that Fiji President Ratu Josefa Iloilo had been informed of the decision, 
as had the chiefs of Vanua Levu, Naitasiri and Tailevu, the areas where the party had most support. Others condemned the merger. Some thought the decision unwise as it would polarize Fiji's ethnic communities, while the military saw it as betrayal of the trust that it had invested in Qarase and the SDL when appointing him prime minister in 2000 .

\section{Constraints}

Two key constraints hindered full participation in the 2006 poll. One was the high number of invalid votes. Of the 3,883 votes cast, 923 were invalid, a similar number to that in the 1999 election, when 958 votes were invalid. It seems that some voters are still not familiar with the voting system, while others may have deliberately invalidated their ballot papers because the person or party of their personal choice was not represented.

Proper voter education is needed to reduce the number of invalid votes. The current 'alternative vote' system, first used in 1999, is relatively new. Before that, Fiji had used the first-past-the-post, simple majority system inherited from the United Kingdom. The new system requires that the voters are well educated in order to vote correctly. It is not enough to have officials from the Elections Office visit the voters to conduct training a few months before the election. This should be on-going, so that the voters understand the system thoroughly, and the number of invalid votes is reduced.

A second constraint arose from the logistics of setting up eight polling stations daily. This consumed a lot of the time and effort of the different candidates. There were instances when Tikoinasau, for example, had set up his sheds at the polling stations in the early hours of the morning. Then, when he came the next day, the shed had been usurped by members of other parties. Setting up polling stations in Tailevu North is not easy, as most of the roads are a challenge to the travelling public.

\section{Conclusion}

The 2006 election saw the voters of Tailevu North expressing the same sentiments as in 2000 and 2001. They were not ready to accept Mahendra Chaudhry as prime minister in 2000, and six years later were still not ready to accept a non-indigenous prime minister. The traditional links between the 
people of this constituency are important, and any politician who disregards this is jeopardizing his or her chances of getting voted into parliament. In addition to traditional links, the service that a candidate has provided to the people is taken into account. Tikoinasau's father had served previously in this constituency and this augured well for Tikoinasau as he sought election for a second term in parliament. The support he received was overwhelming.

Is there hope that the voters of Tailevu North will entertain moderate sentiments in future elections? Perhaps. But in order to accept moderate policies, education is necessary. This would take a long time. It must not be forgotten that these are a people who value their traditional links and are proud to go to battle on behalf of their chief as his warriors. To get them to change their mindset would be to alter the social and traditional fabric of their lives.

\section{Notes}

1 The NVTLP was founded in the late 1990s by a merger of Sakeasi Butadroka's Fijian Nationalist Party and Duvuloco's Vanua Tako Lavo Party, and champions Fijian ethnic nationalism. Both leaders strongly opposed the adoption of the current constitution. Duvuloco calls it a betrayal of the Fijian people. The NVTLP campaigned on a platform of 'Fiji for the Fijians and that their rights at all times should be preserved'.

2 Vulagi is a word used normally to refer to visitors. So those of other ethnic groups are still viewed as visitors though they have lived in Fiji for a long time.

3 Vunivalu na Tui Kaba is the title of the paramount chief of the Kubuna Confederacy.

4 Personal communication, Ratu Naiqama Lalabalavu, 2006.

5 Personal communication, Ratu Naiqama Lalabalavu, 2006.

6 Iqoliqoli is the traditional fishing grounds for a clan/tribe or yavusa, especially for those living in coastal areas.

7 Personal communication, Ratu Naiqama Lalabalavu, 2006.

8 Personal communication, Ratu Naiqama Lalabalavu, 2006.

9 Personal communication, Ratu Naiqama Lalabalavu, 2006. 